\title{
MORAL HAZARD PROBLEM FOR POOR UNDER JOINT FOREST MANAGEMENT PROGRAMME EVIDENCE FROM WEST BENGAL IN INDIAN CONTEXT
}

\author{
Debnarayan Sarker \\ Professor and Secretary, Centre for Economic Studies, Department of Economics Presidency College, \\ 86/1 College Street, Kolkata-73, Email: sarkar_d_n@rediffmail.com
}

\begin{abstract}
This study explores policy framework on current JFM programme, which secures traditional right of local need subject to the carrying capacity of forest, but face moral hazard problem in which Government cannot legally monitor actions against JFM householdswhich live below poverty line and that extract TFPs for their livelihood, and thereby threatening to sustainability of forest, whereas the incentive work opportunities that Government provides them is insufficient for their subsistence. A good incentive fee dependent on their work plus a lump sum fee (subsidy) are required for their livelihood sustenance and sustainability of forest resources.
\end{abstract}

JEL. Classification: Q23, Q56, Q01, Q58.

Key words: Non-Timber Forest Products, Timber Forest Products, Forest wage work, Poor JFM households

\section{Abbreviations used

$\begin{array}{ll}\text { JFMP } & \text { Joint forest management programme } \\ \text { JFM } & \text { Joint forest management } \\ \text { TFPs } & \text { Timber forest products } \\ \text { NTFPs } & \text { Non-timber forest products } \\ \text { TFPs } & \text { Timber forest products } \\ \text { FPCs } & \text { Forest Protection Committees }\end{array}$

It seems to be an important area of research for social scientists to provide policy prescriptions on the current JFM programme, that tries to secure the tradition right of local need of poor forest fringe communities from degraded forest resources by providing their requirements of fuel wood, fodder, minor forest produce, small timber and the share subject to the carrying capacity of forest, which deal with the moral hazard problem for Government, the owner of the JFM forest, because the latter, cannot legally monitor actions against the poor JFM households- which live below poverty line and that extract TFPs for their livelihood sustenance, and thereby threatening to the sustainability of forest resource, whereas the incentive work opportunities provided by Government to those poor JFM households is insufficient for meeting up the bare minimum level of subsistence. This study is an attempt to explore this issue based on a field study in West Bengal state in Indian context.

What is the importance of JFM in Indian Forestry? Several strands have contributed to the present emphasis on community involvement in forest protection in the context of Indian forestry. JFM emerges as the latest in a long history of policy changes, attempting to create a new relationship between 'state' and 'community'. The old custodian forest management systems were rendered ineffective due to various reasons, mainly traditional emphasis on production of commercial wood and disregard for local needs (Sarmah and Rai, 2001:213; Poffenberger, 1995:342-50). To secure the right of local need of poor forest fringe communities from forest resources, the 1988 forest policy of the Government of India recognized the need to fulfill the requirements of fuel wood, fodder, minor forest produce and small timber of rural and tribal people, and emphasized the need to create a massive people's movements for protection and development of forests. But the benefit-sharing arrangements between states and forest communities differ widely between states within the country. But empirical evidence from across the world now confirms that community-based regimes are a viable option for the management of local common property resources (Baland and Platteau, 1996; Berkes, 1989; Bromley, 1992; Correa, 1999; Martin, 1992; Naik, 1995;).

Hence the relevant issue might be: does these benefitsharing arrangement between states and forest communities under community forest management programme meet up the survival need of poor forest communities from forest and thereby restricting the latter's illegal collection of Timber Forest Products (TFPs)? It is argued that the survival of community needs of poor communities should be recognized on a priority basis as pillars for strengthening community participation (Mukherjee, 1995). The most important factors motivating massive local peoples' participation for 
protection and development of forests is the expectations of immediate returns via wages and incomes from sale of old plantation and local consumption need to fill the requirements of fuel wood, fodder, minor forest produce and small timbers (Mukherjee, 1995; Naik, 1997). The Arjuni (an area under JFM programme) experience in JFM of West Bengal shows that unless survival needs of food and livelihood are met, participation in natural resource management would always remain threatened (Mukherjee 1995: 3132). This experience goes a long way to show that survival needs are of prime importance and can easily destabilize community rights and benefits to resource management. The findings of Naik (1997), based on two case studies in Gujarat, help identify the critical factors (survival needs for food and livelihood) in making JFM successful and controllable. Any JFM which does not recognize the significance of creating strategies for sustaining livelihood basic food security - at the local level has a doubtful future (ibid).

The study of Sarker and Das (2006), based on the study of some FPCs under western Midnapore division in West Bengal, shows that for the maintenance of regular consumption needs of the local FPC-households, NTFP is the main source of money income because income from the share of government's timber revenue and wages from forestry work constitute a small part of their total income (p.279-280). Consequently, the NTFP is bound to provide the main and stable source of forestry income and it plays the major role for sustenance of JFM programme (ibid:286). This study also signifies that only government's timber share (without any other share of the forest resource, namely NTFPs) was insufficient to meet the immediate survival needs of poor JFM households. It caused large illicit felling (illegal timber extraction), mainly, by the poor forest communities due to the urgency of meeting immediate seasonal livelihood needs and food insecurity, which plagued the area and led to conditions of semi-starvation among the poor people (p.279).It also implies moral hazard problem for government, the owner of the forest resource, for poor forest communities in particular, because such an illicit felling (illegal timber extraction) might be threatening the sustainability of forest resources.

There are also evidences that despite successful achievements of the JFM programme in West Bengal which safeguards the traditional rights and concessions of the forest fringe communities on forestland by providing them with timber share and the share of NTFPs , Government, the owner of forest resources, also has to face a moral hazard problem for all categories of JFM households in general and for marginal and small categories of one joint FPC village(Baragari JFM village) in particular who engage in the JFM programme as agents of government (Das and Sarker, 2009a: 326-330; 2009b:60). Their study reveals that Government, the principal, cannot legally control the major illegal felling of TFPs by these poor households of Baragari JFM village. Consequently, despite the fact that most of the JFM households decrease their illegal extraction of timber forest product after JFM they practiced before JFM situation, households below poverty line in the said joint FPC village((Baragari FPC village) increase their illegal extraction of TFPs. This is mainly because, their study reveals, the change of income from legal forest products of the poor categories of households of Baragari JFM village after JFM is much lower than that of same categories of households in other FPCs. In all FPCs, except Baragari, the change of income from legal sources of forest is highly positive ranging between 42.91 percentage point and 117.17 percentage point; in Baragari, this change is negative (-12.92 percentage point).Also important is that alternative source of income other than forest source for the poor JFM households is insignificant. It clearly indicates, they argue, that force or law cannot effectively control the illegal collection of TFPs of the poor categories of households, which live below poverty line, until and unless a considerable income from legal forest source meets up their bare minimum level of subsistence (ibid).

One may argue that a good incentive fee dependent on the work (output) would be required for livelihood sustenance of the poor categories of households of Baragari FPC and sustainability of forest resource and thereby reduce the moral hazard problem of Government. But the study of Das and Saker (2009b: 68; 2008:40-1) reveals that the only work opportunity Government provides to JFM households in these areas is forest wage work .Significantly, the number of working days for poor JFM households as wage labour under forest department (Government) is more or less fixed at a fixed wage rate of Rs. 67.50, which is about a double of the prevailing average local wage rate for usually eight hours of service from 8 a.m. to 4 p.m. One person of each JFM household with a family size of five or less gets the opportunity of forest work from 35 to 40 days per year. If the size of member of a household is greater than five, usually, two persons get the opportunity of forest work for 70 to 80 days in total per year from the same family (ibid).Also important is that the increase of opportunity of forest work by forest department (Government) depends on new plantation programme, which is usually long term in nature. The study of Sarker (2009) shows that the production of NTFPs the poor JFM households legally collect from forest do not usually increase within the short period (pp80-1).

In these perspectives one of the vital issues is: if the incentive work opportunities provided by Government to the poor JFM households- which live below poverty line and that extract TFPs for their livelihood sustenance in which government, the owner of the JFM forests, cannot legally monitor actions against them(or force or law cannot effectively control the illegal collection of TFPs) - can hardly be increased in the short period in the JFM forests, how , then, Government should deal with such a moral hazard problem which is threatening to the sustainability of forest resources. In such a situation a good incentive fee dependent on their work (output) might not be sufficient for livelihood sustenance of poor people and sustainability of forest resources. There seems to be two ways to tackle the situation 
by the Government, the owner of the JFM forest- one is to increase the production of NTFPs, fuelwood etc. so that the very poor households may increase their legal collection of those products; the other is to execute a good incentive fee dependent on their work (output) plus a lump sum fee (subsidy) independent of their production for livelihood sustenance of those people and sustainability of forest resources. But the production of forest products (like NTFPs) the very poor households legally collect from forest do not usually increase within the very short period. Then the alternative source to increase the income of the poor households (who live below poverty line and that extract of TFPs for their livelihood sustenance in which government, the owner of the JFM forests, cannot legally monitor actions against them) should be to execute a good incentive fee dependent on their work (output) plus a lump sum fee(subsidy) for livelihood sustenance of those people and sustainability of forest resources by the government.

This study, however, both theoretically and empirically seeks to explore policy framework for dealing with a moral hazard problem for Government who cannot legally monitor actions against poor JFM households, which live below poverty line and that extract Timber forest products, which is threatening to the sustainability of forest resources, for their livelihood sustenance under JFM programme in a situation where the incentive work opportunities provided by Government to those poor JFM households is insufficient for meeting up the bare minimum level of subsistence. The underlying hypothesis is that a good incentive fee dependent on forest wage work (output) for JFM households plus a lump sum fee( subsidy) independent of forest work are required for livelihood sustenance of JFM households and sustainability of forest resources.

This paper proceeds as follows. Section II presents the importance of the study. Section III provides a simple theoretical model based on the hypothesis of the study. The data set and methodology appear in section IV. Section V presents the key results of the empirical study in keeping with the objective of the study. Conclusions are contained in section VI.

\section{Section II}

An optimal contracting arrangement by the government JFM household framework - can be defined as follows: A contract is optimal if it maximizes the expected utility of the government for an expected utility of the JFM household subject to the condition that the JFM household finds it worthwhile to participate in the contract. As is well known, government is the owner of forest land and under JFM programme government employs JFM household (agent) to work under the former for the management of forest resources. Let us suppose that there are only a finite number of output levels $\left(\mathrm{q}_{1}, \mathrm{q}_{2}, \mathrm{q}_{3}, \ldots \mathrm{q}_{\mathrm{n}}\right)$. Let $\mathrm{v}$ and $\mathrm{r}$ be two efforts that can be chosen by the JFM household (agent) out of some set of feasible efforts. These efforts influence the probability of occurrence of different output levels. Let us suppose that the probability that the output level $\mathrm{q}_{\mathrm{i}}$ will occur if the agent chooses effort $\mathrm{v}(\mathrm{r})$ by $\pi_{\mathrm{iv}}\left(\pi_{\mathrm{ir}}\right)$. Let $\mathrm{x}_{\mathrm{i}}=\mathrm{x}\left(\mathrm{q}_{\mathrm{i}}\right)$ be the amount that the government pays the JFM household if output level $\mathrm{q}_{\mathrm{i}}$ is observed. We denote the lump sum fee (subsidy) $\mathrm{k}$, the minimum subsistence level of JFM household, independent of $\mathrm{q}_{\mathrm{i}}$. Then the expected profit of the principal (government), if agent (JFM household) chooses action $\mathrm{v}$, is

$$
\sum_{i=1}^{n}\left(q_{i}-x_{i}\right) \pi_{i v}-\sum_{i=1}^{n} k_{i}
$$

The expected profit is assumed to be linear in $\mathrm{q}_{\mathrm{i}}$. It implies that the principal is risk-neutral ${ }^{1}$. We assume that the agent is risk-averse ${ }^{2}$ and maximizes the expected utility from the payment. We also assume that the JFM household (agent) finds efforts costly, and write $\mathrm{c}(\mathrm{v})$ be the cost of effort $\mathrm{v}$. The cost enters into JFM household's utility function linearly. If JFM household chooses effort $\mathrm{v}$, his/her expected utility less cost is given by

$$
\left[\sum_{\mathrm{i}=1}^{\mathrm{n}}\left\{\mathrm{u}\left(\mathrm{x}_{\mathrm{i}}\right) \pi_{\mathrm{iv}}\right\}+\sum_{\mathrm{i}=1}^{\mathrm{n}} \mathrm{k}_{\mathrm{i}}\right]-\mathrm{c}(\mathrm{v})
$$

, where $\mathrm{u}$ is the Von Neumann-Morgenstern utility function of the JFM household (agent).

Two types of constraints are imposed on JFM household in this self-enforcing contract (non-enforceability in the courts does not make contracts valueless. The contract acts in such a way that each party chooses to adhere to its term) participation constraint and incentive comparability constraint.

Since the JFM household is a utility maximiser, he/she will choose action $\mathrm{u}$ if

$$
\left.\left[\sum_{\mathrm{i}=1}^{\mathrm{n}}\left\{\mathrm{u}\left(\mathrm{x}_{\mathrm{i}}\right) \pi_{\mathrm{iv}}\right\}+\sum_{\mathrm{i}=1}^{\mathrm{n}} \mathrm{k}_{\mathrm{i}}\right]-\mathrm{c}(\mathrm{v}) \geq\left[\sum_{\mathrm{i}=1}^{\mathrm{n}}\left\{\mathrm{u}\left(\mathrm{x}_{\mathrm{i}}\right) \pi_{\mathrm{iv}}\right\}+\sum_{\mathrm{i}=1}^{\mathrm{n}} \mathrm{k}_{\mathrm{i}}\right]-\mathrm{c}(\mathrm{r}) 2\right)
$$

and will choose effort $r$ otherwise.

This constraint is referred to as the incentive compatibility constraint. The second type of constrain says that the JFM household may have other alternatives available that give him/her some utility $\overline{\mathrm{u}}$. Then the participation constrain is

$$
\left[\sum_{\mathrm{i}=1}^{\mathrm{n}}\left\{\mathrm{u}\left(\mathrm{x}_{\mathrm{i}}\right) \pi_{\mathrm{iv}}\right\}+\sum_{\mathrm{i}=1}^{\mathrm{n}} \mathrm{k}_{\mathrm{i}}\right]-\mathrm{c}(\mathrm{v}) \geq \overline{\mathrm{u}}
$$

The expected utility the JFM household gets from this job must be at least as great as the utility he/she could get elsewhere.

If the payment is based on effort rather than on output, then the government is to determine the expected profit from each effort by the JFM household and then induce the effort that minimizes government's expected profit. But as the efforts of the JFM household are hidden, payment to him/her can not be a function of the unobservable effort $(\mathrm{v}, \mathrm{r})$. It can be made contingent on the observed output $\mathrm{q}_{\mathrm{i}}$. Attempt has been made to develop results along this line. Suppose that there is no incentive problem. However under the risk-neutrality assumption the government is indifferent to risk and thus there is no need to trade off incentives for risk-sharing. In such a case the principal's (government's) optimization problem is 


$$
\begin{gathered}
\sum_{\mathrm{i}=1}^{\mathrm{n}}\left(\mathrm{q}_{\mathrm{i}}-\mathrm{x}_{\mathrm{i}}\right) \pi_{\mathrm{iv}}-\sum_{\mathrm{i}=1}^{\mathrm{n}} \mathrm{k}_{\mathrm{i}} \\
{\left[\sum_{\mathrm{i}=1}^{\mathrm{n}}\left\{\mathrm{u}\left(\mathrm{x}_{\mathrm{i}}\right) \pi_{\mathrm{iv}}\right\}+\sum_{\mathrm{i}=1}^{\mathrm{n}} \mathrm{k}_{\mathrm{i}}\right]-\mathrm{c}(\mathrm{v}) \geq \overline{\mathrm{u}}}
\end{gathered}
$$

where maximization is taken place over $\mathrm{x}_{\mathrm{i}}$.

In general, government will want the JFM household to choose xi to just satisfy the constraint so that

$$
\left[\sum_{\mathrm{i}=1}^{\mathrm{n}}\left\{\mathrm{u}\left(\mathrm{x}_{\mathrm{i}}\right) \pi_{\mathrm{iv}}\right\}+\sum_{\mathrm{i}=1}^{\mathrm{n}} \mathrm{k}_{\mathrm{i}}\right]-\mathrm{c}(\mathrm{v}) \geq \overline{\mathrm{u}}
$$

The Lagrangian for this optimization problem is

$$
\mathrm{L}=\sum_{\mathrm{i}=1}^{\mathrm{n}}\left(\mathrm{q}_{\mathrm{i}}-\mathrm{x}_{\mathrm{i}}\right) \pi_{\mathrm{iv}}-\lambda\left(\left[\sum_{\mathrm{i}=1}^{\mathrm{n}}\left\{\mathrm{u}\left(\mathrm{x}_{\mathrm{i}}\right) \pi_{\mathrm{iv}}\right\}+\sum_{\mathrm{i}=1}^{\mathrm{n}} \mathrm{k}_{\mathrm{i}}\right]-\mathrm{c}(\mathrm{v})-\overline{\mathrm{u}}\right)
$$

where $\lambda$ is the Lagrange multiplier.

Government is risk-neutral because her expected profit is linear in $x_{i}$. Differentiating $L$ partially with respect to $x_{i}$ and $\lambda$, and setting the derivatives to zero, we have the first order conditions as

$$
\begin{aligned}
& -\pi_{i v}-\lambda u^{\prime}\left(x_{i}\right) \pi_{i v}=0 \\
& {\left[\sum_{i=1}^{n}\left\{u\left(x_{i}\right) \pi_{i v}\right\}+\sum_{i=1}^{n} k_{i}\right]-c(v)-\bar{u}=0}
\end{aligned}
$$

The first of the above conditions states $u^{\prime}\left(x_{i}\right)=1 / \lambda$, a constant. i.e., $x_{i}$ must be independent of $i$ ( $x_{i}$ is a constant).

The model assumes that that the wage rate for each individual of JFM household, who work under forest department as forest wage labour, is fixed (Das and Saker (2009b: 68; 2008:41). What it implies that $\mathrm{x}_{\mathrm{i}}$ is independent of $i$. The wage rate does not depend on the return (high or low) of forest wage work of JFM household.

This theoretical model tries to explore that a good incentive fee dependent on their work (output) might not only provide livelihood sustenance of poor people living below poverty line and ensure sustainability of forest resources; rather a good incentive fee dependent on their work (output) plus a lump sum fee (subsidy) are required for livelihood sustenance of those people and sustainability of forest resources. This theoretical model is important in that moral hazard problem that appears from asymmetric information is a trade - off between risk bearing and incentives; but such a trade-off cannot provide livelihood sustenance to poor people living below poverty line under JFM programme, because the potential financial and economic liabilities the government have to bear for their agents (poor JFM households) is more than the former's expected return(i.e., the return of the incentives) they expect to receive from their agents- work (output).

\section{Section III}

As is well known, The Forest Conservation Act of 1980 and the 1988 National Forest Policy in India marks a major departure from the earlier policies which emphasis on production of commercial wood and disregard for local need
(Poffenberger, 1995; World Bank, 2006: xvi; Sarmah and Rai, 2000: 213), because Government of India, then, could understand that until and unless the benefit of forest fringe communities is secured, neither forest resources nor forest management can be sustainable. In order to execute sustainable forest management system, the active participation of local forest communities in forest management for conservation and development plans of forest resources and the participatory forest management on usufruct sharing basis for safeguarding their traditional rights subject to the carrying capacity of forest was first introduced and implemented by the National Forest Policy of 1988.

If we look into the historical perspective of Joint Forest Management programme in West Bengal in particular, we find that, in keeping with the other parts of India, the local forest fringe communities of West Bengal have also mobilized repeatedly from long past against the custodian forest management system (commercial need either of the government or of the rulers of India) to protect their traditional right on forest (Poffenberger, 1995). With regard to the south West Bengal (Midnapore, Bankura, Purulia Burdwan and Birbhum), including our study area, is concerned, Santal, Bhumij and Mahato tribal, with some low caste Hindus, mobilized repeatedly against Mughal and British rulers to protect their traditional rights on forestland from long past. Chur Rebellion (from 1767 to 1805), Naik Revolt (1806-16), Hul Rebellion (1855) are the glaring examples of the history in south West Bengal where forest fringe communities organized resistance against rulers of India to protect their own right in forestland.

However, far-reaching developments in the historic, demographic, economic, social and environmental fields have resulted in the revision of the National Forest Policy in 1988. But despite the fact that successful examples of joint forest management in India were beginning to emerge in the Arabari Hill in Midnapore district of West Bengal during the early 1970s (Sundar and Jeffery, 1999:28), the JFM movement gathered momentum when in 1989 a programme of resuscitation and reestablishment of moribund sal and other hardwood forests in the districts of Midnapore, Bankura, Purulia, Burdwan and Birbhum in south West Bengal was initiated by the government with the active participation and involvement of the local people. In keeping with the JFM movement in India, West Bengal government's resolution was also issued in 1989, declaring the principles of sharing of duties, responsibilities as well as the usufructs from the forests to the participant local people living in the fringe of the forests. The procedures for establishment of the institution called Forest Protection Committee (FPC), comprising of these participants as members, were also defined.

The foundation of an innovative forest protection system and the participatory forest management was thus laid for the forests of south West Bengal which covers approximately 38 per cent of the total forest area of the State. While explaining the achievements of JFM programme in West Bengal, West Bengal State Forest Report (2000) clearly mentions:

"As a result of participatory and joint forest management activities in south West Bengal the vast tract of scattered, 
over-exploited and degraded forests containing mainly the sal were resuscitated and restored to productivity with great improvement in quality and density " (SFR, 2000:47). These participatory activities are now progressing in other areas of the state as well.

Government report (SFR, 2000) reveals that the overexploitation of trees for timber was so severe that thousand and thousand hectares of forest lands in the south West Bengal except Sundarban were almost treated as bare plain land, when the JFM was established; but such lands are almost secured after JFM programme. Secondly, government revenue from the degraded forest was almost nil when the JFM was established, but it has significantly increased after JFM (Das and Sarker, 2008: 82-91; Sarkar and Das, 2008:22; Das and Sarker; 2009a: 324).

Despite such a successful achievement of JFM programme in West Bengal, some poor JFM households have higher incidence in the illegal extraction of Timber Forest Products (TFPs) to meet up their bare minimum level of subsistence in which law or force cannot effectively control the illegal extraction of TFPs of these poor JFM households, which live below poverty line (Das and Sarker, 2008:91; Sarker and Das, 2008:35; Das and Sarker, 2009a:59; 2009b: 326-330; Sarker, 2009:78). It is, no doubt, a moral hazard problem for the Government because such an illegal extraction of TFPs by the JFM household might be threatening the sustainability of forest resources. Moreover, the pressure of population on forests in the long run might lead to substantial damage of forest resource, causing acute environmental damage for West Bengal in future.

This empirical study, however, tries to explore policy framework as to how both livelihood sustenance of poor JFM households and sustainability of forest resources can attained simultaneously. This empirical study is important in that it might help us examine whether the 1988 Forest Policy of India and thereafter West Bengal Government' JFM resolution in June 1989, which for the first time specifies the rights of the protecting communities with the help of establishing Forest Protection Committees/Village Forest Committees over forest lands, has been effective on meeting the local needs in particular of the tribal and the poor living near the forests and in safeguarding their traditional right and concession subject to the carrying capacity of forests .

\section{Section IV}

In order to examine our stated objectives based on both female and joint FPCs, we mainly depend on field survey in Midnapore and Bankura districts of West Bengal. The inclusion of Midnapore district under our field survey is due to the fact that the key precursor to JFM from the managerial perspective was a local level initiative, which was started from the Arabari hills under Midnapore district of West Bengal during the early 1970s. Moreover, as we attempt to examine the stated objectives in both the female and joint FPCs, some female FPCs are also in operation along with joint FPCs in Midnapore district. The main argument behind the inclusion of Bankura district under our study may be judged by the fact that female FPCs were first established in Bankura districts in West Bengal during early 1990's and the majority of female FPCs are now running in Bankura district. As per the official records (State Forest Report, Government of West Bengal 2000) 17 female FPCs are in operation in Bankura district - 4 in Bankura North, 9 in Bankura South and 4 in Panchet forest divisions (Sarker and Das, 2002:4410). However, during the first year of my UGC Minor Research Project entitled "How to execute the Joint Forest Management Programme with Sustainability?" a study of Joint FPC and Female FPC in four divisions under Midnapore and Bankura districts in West Bengal, we conducted our field survey in four FPCs based on stratified random sampling method from different forest ranges under two forest divisions - one in West Midnapore (Midnapore district) and the other in North Bankura (Bankura district). First, forest divisions and then forest ranges were selected by purposive sampling, but the selection of sub-samples- FPCsfrom within the selected ranges depends purely on chance. Two FPCs were selected from Gidini Range and one, from Hatibari Range under West Midnapore division. Two Female FPCs are in operation in Gidini Range under West Midnapore district - Kherajhore Female FPC and Depudanga Female FPC. Kherajhore Female FPC was randomly selected from them for our field study. We also randomly selected one Joint FPC based on the total Joint FPCs under Gidini Range. Under Hatibari Range in West Midnapore division, no Female FPC is in operation. However, we randomly selected one Joint FPC (Goulbur Marshal) from out of all Joint FPCs under Hatibari Range. One Joint FPC was also randomly selected from Gangajalghati Range under North Bankura division (Bankura district) as there is no female FPC in this range. However four FPCs - one Female FPC and three Joint FPCs - were selected based on stratified random sampling method. Firstly, districts, forest divisions and then forest ranges were selected by the purposive method. Finally, the selection of sub-samples of FPC from three forest ranges depends purely on chance (Simple Random Sampling Without Replacement). The subdivision of the population into strata is done by the purposive method, but the selection of subsamples within the final strata (forest ranges) depends purely on chance. However, our final survey considers all units of households (134 in number) - Kherajhore (32), Khatgeria (17), Goulbermarshal (59) and Amjuri (26) - in four FPCs. The data of these four sample FPCs were considered for two situations - before JFM and after JFM. The period of collecting data for 'after situation' in all FPCs is samebetween February and October 2005. But the period of data for 'before situation' was not same to all FPCs. JFM programme in Kherajhore, Khatgeria, goulbermarsha and Amjuri was started on March 1994, August 1995, May 1994 and July 1995 respectively. 'Before situation' for each FPC is considered for the preceding one-year period from the starting of JFM programme in the respective FPC. For 
example, 'before situation' in Kherajhore FPC was between March 1993 and February 1994. It is worth mentioning that each FPC was formed in the respective village; so the FPC/village is synonymous in this study. They will be referred to as 'JFM village 'in the section of the' key results of the empirical study".

In the empirical part this study considers simple technique of measurement like arithmetic mean, proportions, paired t test for equality of two means for examining our stated objectives, and tabular analysis for examining our stated objectives.

\section{Section V}

All sample villages fall into the semi-arid agro-climatic category with red soils, insufficient rainfall and not good in terms of moisture retention. The socio economic profile of the sample villages is presented in Table 1. It shows that all households belong to either very poor or poor category in two (Goulber Marshal and Amjuri) out of four villages. Out of the remaining villages the incidence of very poor and poor category in Kherajhore and Khatgeria works out to about 93.75 and 70.59 per cent respectively. Although more than two-fifths of the households are landless in all JFM villages, the incidence of landless households is relatively high in Amjuri (73.07 per cent) and Goulbur Marshal (57.62 per cent). Worthwhile to mention that both very poor and poor income group in all JFM villages live below poverty line. These classifications (very poor, poor and medium) have been taken from Bezbaruah (2004). Also important is that , one may calculate real income after deflating the money income by cost of living index; but there would be, hardly, any change in the money income for the classification of households (very poor, poor and medium) that appears from Bezbaruah (2004) during the period of our survey(between February and October 2005). As regards the caste status is concerned, all the households in two (Goulber Marshal and Amjuri) out of four villages belong to ST category and the average size of household members in these two

Table 1. Socio - Economic Characteristics of the Sample FPCs/Village

\begin{tabular}{|c|c|c|c|c|c|c|c|c|c|c|}
\hline \multirow{2}{*}{$\begin{array}{l}\text { FPC/ } \\
\text { Village }\end{array}$} & \multirow{2}{*}{$\begin{array}{c}\text { No. of } \\
\mathrm{HH}\end{array}$} & \multirow{2}{*}{$\begin{array}{c}\text { Average } \\
\text { size of } \\
\text { HH }\end{array}$} & \multirow{2}{*}{$\begin{array}{c}\text { Average } \\
\text { size of Land } \\
\text { Holding } \\
\text { (acres) }\end{array}$} & \multicolumn{3}{|c|}{ HH belonging to Wealth Category } & \multicolumn{2}{|c|}{$\%$ of $\mathrm{H} \mathrm{H}$ belonging to } & \multicolumn{2}{|c|}{$\%$ of FPC member } \\
\hline & & & & $\begin{array}{l}\text { Very } \\
\text { Poor* }\end{array}$ & Poor** & Medium*** & $\mathrm{SC}$ & ST & Illiterate & $\begin{array}{c}\text { Primary } \\
\text { Edn. }\end{array}$ \\
\hline Kherajhore & 32 & 4.30 & $3.25(24)$ & $18[14]$ & 12 & 2 & 6.25 & 3.13 & 56.25 & 37.50 \\
\hline Khatgeria & 17 & 4.68 & $3.52(18)$ & 7[7] & 5 & 5 & - & 14.18 & 58.82 & 29.41 \\
\hline Goulber Marshal & 59 & 6.38 & $2.65(49)$ & $38[34]$ & 21 & - & - & 100 & $66 . .10$ & 20.34 \\
\hline Amjuri & 26 & 6.02 & $1.35(14)$ & $23[19]$ & 3 & - & - & 100 & $69 . .23$ & 26.92 \\
\hline
\end{tabular}

Note: HH=Households. Figures in ( ) indicate percentage of area under Wastelands. Wastelands include private as well as common lands that are not being cultivated. Figures in [] indicate number of landless labour households.

* Indicates per capita annual income within the range of Rs.0-8500;

** implies per capita annual income within the range of above Rs.8500-11000;

*** represents per capita annual income within the range of above Rs.11000-13000. Both very poor and poor income groups live below poverty line. These classifications (very poor, poor and medium) have been taken from Bezbaruah (2004).

Source: Sample Survey.

Table 2. Change (\%) in the Availability of Fodder (per standard cattle per day)

\begin{tabular}{|l|l|c|c|c|}
\hline \multirow{2}{*}{$\begin{array}{l}\text { FPC/ } \\
\text { Village }\end{array}$} & $\begin{array}{l}\text { Category } \\
\text { of HH } \\
\text { (Wealth) }\end{array}$ & \multicolumn{3}{|c|}{$\begin{array}{l}\text { Fodder availability (Kg/Day/Standard } \\
\text { Livestock) in the sample Households }\end{array}$} \\
\cline { 2 - 5 } & Before & After & \% Change* \\
\hline \multirow{4}{*}{ Kherajhore } & Very Poor & $4.8(3.8)$ & $8.2(6.4)$ & $70.83(2.6)$ \\
\cline { 2 - 5 } & Poor & $6.3(5.4)$ & $9.5(8.6)$ & $50.79(3.2)$ \\
\cline { 2 - 5 } & Medium & $12.6(10.6)$ & $16.8(14.8)$ & $30.33(4.2)$ \\
\hline \multirow{4}{*}{ Khatgeria } & Very Poor & $5.3(4.2)$ & $12.6(9.6)$ & $137.74(5.4)$ \\
\cline { 2 - 5 } & Poor & $8.5(6.3)$ & $12.5(10.8)$ & $47.06(4.5)$ \\
\cline { 2 - 5 } & Medium & $12.5(9.4)$ & $16.4(13.8)$ & $31.20(4.4)$ \\
\hline \multirow{2}{*}{ Marshal } & Very Poor & $6.5(5.6)$ & $11.6(10.4)$ & $78.46(4.8)$ \\
\cline { 2 - 5 } & Poor & $9.8(7.4)$ & $12.8(10.6)$ & $30.61(3.2)$ \\
\hline & Very Poor & $5.3(4.8)$ & $12.6(11.4)$ & $137.73(6.6)$ \\
\cline { 2 - 5 } & Poor & $8.2(6.3)$ & $13.8(90.6)$ & $68.29(4.3)$ \\
\hline
\end{tabular}

Note : Standard livestock is arrived at by converting small livestock on a $3: 1$ ratio to big livestock.

Figures( ) indicate average number of standard cattle unit per household

* Indicates that the difference is statistically significant at 5 per cent level.

Source: Sample Survey.
Table 3. Change (\%) in Fuelwood collection per day

\begin{tabular}{|l|l|c|c|c|}
\hline \multirow{2}{*}{$\begin{array}{l}\text { FPC/ } \\
\text { Village }\end{array}$} & \multirow{2}{*}{$\begin{array}{l}\text { Category } \\
\text { of HH } \\
\text { (Wealth) }\end{array}$} & \multicolumn{3}{|c|}{ Quantity of Fuelwood (Quintals) } \\
\cline { 3 - 5 } & Before & After & $\%$ Change* \\
\hline \multirow{4}{*}{ Kherajhore } & Very Poor & $21.00(1.17)$ & $40.00(2.22)$ & $19.00(1.05)$ \\
\cline { 2 - 5 } & Poor & $9.00(0.75)$ & $18.5(1.54)$ & $9.5(0.79)$ \\
\cline { 2 - 5 } & Medium & $0.30(0.15)$ & $0.35(0.18)$ & $0.05(0.03)$ \\
\hline \multirow{4}{*}{ Khatgeria } & Very Poor & $5.00(0.71)$ & $14.5(2.07)$ & $9.5(1.36)$ \\
\cline { 2 - 5 } & Poor & $2.00(0.40)$ & $7.5(1.50)$ & $5.5(1.1)$ \\
\cline { 2 - 5 } & Medium & - & - & - \\
\hline \multirow{3}{*}{$\begin{array}{l}\text { Goulber } \\
\text { Marshal }\end{array}$} & Very Poor & $28.00(0.74)$ & $43.5(1.14)$ & $15.5(0.4)$ \\
\cline { 2 - 5 } $\begin{array}{l}\text { Amjuri } \\
\text { Poor }\end{array}$ & Poor & $10.00(0.48)$ & $19.5(0.92)$ & $9.5(0.44)$ \\
\cline { 2 - 5 } & Very Poor & $15.75(0.68)$ & $42.00(1.83)$ & $26.25(1.15)$ \\
\hline
\end{tabular}

Note : ${ }^{*}$ Indicates that the difference is statistically significant at 1 per cent level.

Figures in ( ) indicate average quantity of fuelwood(Quintals) per household. Source: Sample Survey. 
Table 4. Change (\%) in the Non-Timber Forest Products (NTFPs) collection by the Sample Households per day.

\begin{tabular}{|c|c|c|c|c|c|c|c|c|c|c|}
\hline \multirow[t]{3}{*}{ FPC/Village } & \multirow{3}{*}{$\begin{array}{l}\text { Category } \\
\text { HH (Wealth) }\end{array}$} & \multicolumn{8}{|c|}{ Quantity of NTFPs (KG) } & \multirow{3}{*}{$\begin{array}{c}\% \text { Change } \\
\text { of total }^{*}\end{array}$} \\
\hline & & \multicolumn{4}{|c|}{ Before } & \multicolumn{4}{|c|}{ After } & \\
\hline & & $\begin{array}{c}\text { Sal } \\
\text { Leaves }\end{array}$ & $\begin{array}{l}\text { Kendu } \\
\text { Leaves }\end{array}$ & Others & Total & $\begin{array}{c}\text { Sal } \\
\text { Leaves }\end{array}$ & $\begin{array}{l}\text { Kendu } \\
\text { Leaves }\end{array}$ & Others & Total & \\
\hline \multirow[t]{3}{*}{ Kherajhore } & Very Poor & 42 & 15 & 10 & $\begin{array}{c}67 \\
(3.72)\end{array}$ & 128 & 69 & 22 & $\begin{array}{c}219 \\
(12.17)\end{array}$ & $\begin{array}{c}226.87 \\
(8.45)\end{array}$ \\
\hline & Poor & 20 & 08 & 06 & $\begin{array}{c}34 \\
(2.83) \\
\end{array}$ & 69 & 37 & 14 & $\begin{array}{c}120 \\
(10.00) \\
\end{array}$ & $\begin{array}{c}252.94 \\
(7.17) \\
\end{array}$ \\
\hline & Medium & 02 & - & - & $\begin{array}{c}02 \\
(1.0)\end{array}$ & - & - & - & - & $\begin{array}{l}-100 \\
(-1.0)\end{array}$ \\
\hline \multirow[t]{3}{*}{ Khatgeria } & Very Poor & 16 & 10 & 07 & $\begin{array}{c}33 \\
(4.71) \\
\end{array}$ & 47 & 25 & 18 & $\begin{array}{c}90 \\
(12.86) \\
\end{array}$ & $\begin{array}{l}172.73 \\
(8.15) \\
\end{array}$ \\
\hline & Poor & 07 & 08 & 06 & $\begin{array}{c}21 \\
(4.20) \\
\end{array}$ & 28 & 19 & 11 & $\begin{array}{c}58 \\
(11.60) \\
\end{array}$ & $\begin{array}{l}176.19 \\
(7.40) \\
\end{array}$ \\
\hline & Medium & - & 02 & - & $\begin{array}{c}02 \\
(0.40) \\
\end{array}$ & - & 05 & - & $\begin{array}{c}05 \\
(1.0)\end{array}$ & $\begin{array}{c}150 \\
(0.60)\end{array}$ \\
\hline \multirow[t]{2}{*}{$\begin{array}{l}\text { Goulber } \\
\text { Marshal }\end{array}$} & Very Poor & 80 & 64 & 32 & $\begin{array}{c}176 \\
(4.63) \\
\end{array}$ & 92 & 106 & 67 & $\begin{array}{c}265 \\
(6.97) \\
\end{array}$ & $\begin{array}{l}50.57 \\
(2.34) \\
\end{array}$ \\
\hline & Poor & 38 & 28 & 16 & $\begin{array}{c}82 \\
(3.90)\end{array}$ & 47 & 45 & 36 & $\begin{array}{c}128 \\
(6.10)\end{array}$ & $\begin{array}{l}56.10 \\
(2.20)\end{array}$ \\
\hline \multirow[t]{2}{*}{ Amjuri } & Very Poor & 72 & - & 11 & $\begin{array}{c}83 \\
(3.61) \\
\end{array}$ & 167 & - & 32 & $\begin{array}{c}199 \\
(8.65) \\
\end{array}$ & $\begin{array}{c}139.76 \\
(5.04) \\
\end{array}$ \\
\hline & Poor & 07 & - & 02 & $09(3.0)$ & 20 & - & 07 & $\begin{array}{c}27 \\
(9.0)\end{array}$ & $\begin{array}{c}200 \\
(6.0)\end{array}$ \\
\hline
\end{tabular}

Note: Figure in ( ) indicate average quantity of NTFPs (KG) per household per day.

*Indicates that the difference is statistically significant at 1 per cent level.

Source: Sample Survey.

FPCs/Villages is relatively high in relation to the rest ones. The majority of households in other two villages belong to general category. In fact, agriculture and its allied activities are the main source of income of the households in our sample villages. A considerable portion of land in each village is under wastelands, which are not cultivated. Therefore, dependence on forest resources under JFM programme is expected to have a substantial impact on the livelihood of most of these households.

But the dependence of forest resource for JFM households in the area we surveyed is measured in terms of changes in access to fodder, fuelwood, NTFPs and TFPs (Timber Forest Products) that act as a flow input into livelihood activities of household as well as community level in the study. Livestock rearing is an important livelihood strategy in the sample JFM villages. The availability of fodder on a sustainable basis is the key for the sustainability of livestock rearing. Table 2 shows that fodder availability has made a significant increase in all the sample villages for JFM Programme, the rate of increase being more prominent among the households of very poor category, and medium category is the least beneficiaries by these shifts. This is also true in terms of changes in access to daily fuelwood collection (Table 3), daily collection of NTFPs (Table 4), which are also a key to the livelihood security for households we surveyed. But with regard to the changes in the collection of timber forest products (TFPs) per day by the sample households are concerned, Table 5 shows that the rate of change of quantity of TFPs (Kg) per day has significantly
Table 5. Change (\%) in Timber Forest Products'(TFPs) collection per day

\begin{tabular}{|l|l|c|c|c|}
\hline \multirow{2}{*}{$\begin{array}{l}\text { FPC/ } \\
\text { Village }\end{array}$} & $\begin{array}{l}\text { Category } \\
\text { of HH } \\
\text { (Wealth) }\end{array}$ & \multicolumn{3}{|c|}{ Quantity of TFPs (Kg) per day } \\
\cline { 2 - 5 } & & Before & After & $\%$ Change* \\
\hline \multirow{4}{*}{ Kherajhore } & Very Poor & $65(3.11)$ & $6(0.33)$ & $-90.77(-2.78)$ \\
\cline { 2 - 5 } & Poor & $16(1.33)$ & $4(0.33)$ & $-75.00(-1.0)$ \\
\cline { 2 - 5 } & Medium & $5(2.50)$ & - & $-100.00(-2.50)$ \\
\hline \multirow{4}{*}{ Khatgeria } & Very Poor & $24(3.43)$ & $5(0.71)$ & $-79.17(-2.72)$ \\
\cline { 2 - 5 } & Poor & $13(2.6)$ & $2(0.40)$ & $-84.62(-2.20)$ \\
\cline { 2 - 5 } & Medium & $12(2.40)$ & - & $-100.00(2.40)$ \\
\hline \multirow{3}{*}{ Marshal } & Very Poor & $42(1.11)$ & $162(4.26)$ & $285.71(3.15)$ \\
\cline { 2 - 5 } & Poor & $19(0.90)$ & $35(1.67)$ & $84.21(0.77)$ \\
\hline Amjuri & Very Poor & $30(1.30)$ & $10(0.43)$ & $-66.67(-0.87)$ \\
\cline { 2 - 5 } & Poor & $5(1.67)$ & $2(0.67)$ & $-60.00(-1.0)$ \\
\hline
\end{tabular}

Note : Figures in ( ) indicate average quantity of TFPs $(\mathrm{Kg})$ per household . *Indicates that the difference is statistically significant at 1 per cent level. Source: Sample Survey.

decreased in three JFM villages except one (Goulber Marshal) for the execution of JFM Programme. The significant decrease of the collection of TFPs in most of the JFM villages is desirable because law forbids the collection of TFPs by the households other than Forest Department/Government. Rather the members of the JFM village are entitled to have a fixed share of TFPs (usually 20 to 25 per cent of total income from TFPs) from forest department/government. Despite the fact that law prohibits the collection of TFPs, very poor and poor households under our 
Table 6. Incremental Annual Net Revenue (Rs.) from All Sources of Sample Households.

\begin{tabular}{|c|c|c|c|c|c|c|c|c|c|c|}
\hline \multirow[b]{2}{*}{ FPC/Village } & \multirow[b]{2}{*}{$\begin{array}{l}\text { Category } \\
\text { HH (Wealth) }\end{array}$} & \multicolumn{3}{|c|}{ Before } & \multicolumn{3}{|c|}{ After } & \multicolumn{3}{|c|}{$\%$ Change } \\
\hline & & $\begin{array}{c}\text { Net Return } \\
\text { from Forest } \\
\text { sources }\end{array}$ & $\begin{array}{c}\text { Net Return } \\
\text { from other } \\
\text { sources }\end{array}$ & $\begin{array}{l}\text { Net Return } \\
\text { from all } \\
\text { sources }\end{array}$ & $\begin{array}{c}\text { Net Return } \\
\text { from Forest } \\
\text { sources }\end{array}$ & $\begin{array}{l}\text { Net Return } \\
\text { from other } \\
\text { source }\end{array}$ & $\begin{array}{l}\text { Net Return } \\
\text { from all } \\
\text { sources }\end{array}$ & $\begin{array}{c}\text { Net Return } \\
\text { from Forest } \\
\text { source* }\end{array}$ & $\begin{array}{l}\text { Net Return } \\
\text { from other } \\
\text { sources* }\end{array}$ & $\begin{array}{l}\text { Net Return } \\
\text { from all } \\
\text { sources* }\end{array}$ \\
\hline \multirow[t]{3}{*}{ Kherajhore } & Very Poor & $\begin{array}{c}314079 \\
(17448.83) \\
\end{array}$ & $\begin{array}{c}177427 \\
(9857.06)\end{array}$ & $\begin{array}{l}491506 \\
{[63.90]} \\
\end{array}$ & $\begin{array}{l}517608 \\
(28756) \\
\end{array}$ & 132664 & $\begin{array}{l}650272 \\
{[79.60]} \\
\end{array}$ & 64.80 & -25.23 & 32.30 \\
\hline & Poor & $\begin{array}{c}191253 \\
(15937.75)\end{array}$ & $\begin{array}{c}227945 \\
(18995.42)\end{array}$ & $\begin{array}{l}419198 \\
{[45.62]}\end{array}$ & $\begin{array}{c}293522 \\
(24460.17)\end{array}$ & $\begin{array}{c}228773 \\
(19064.42) \\
\end{array}$ & $\begin{array}{l}522295 \\
{[56.20]}\end{array}$ & 53.47 & 0.36 & 24.59 \\
\hline & Medium & $\begin{array}{c}20623 \\
(10311.50) \\
\end{array}$ & $\begin{array}{c}70216 \\
(35108) \\
\end{array}$ & $\begin{array}{l}90839 \\
{[22.70]}\end{array}$ & $\begin{array}{c}18972 \\
(9486.00) \\
\end{array}$ & $\begin{array}{c}86060 \\
(43030.00) \\
\end{array}$ & $\begin{array}{l}105032 \\
{[18.06]}\end{array}$ & -8.01 & 22.56 & 15.62 \\
\hline \multirow[t]{3}{*}{ Khatgeria } & Very Poor & $\begin{array}{l}114247 \\
(16321) \\
\end{array}$ & $\begin{array}{c}80383 \\
(11483.29) \\
\end{array}$ & $\begin{array}{l}194630 \\
{[58.70]}\end{array}$ & $\begin{array}{c}195727 \\
(27961.00) \\
\end{array}$ & $\begin{array}{c}14592 \\
(2084.57) \\
\end{array}$ & $\begin{array}{l}210319 \\
{[93.06]}\end{array}$ & 71.32 & -81.85 & 80.61 \\
\hline & Poor & $\begin{array}{c}79024 \\
(15804.80)\end{array}$ & $\begin{array}{c}103776 \\
(20755.20)\end{array}$ & $\begin{array}{l}182800 \\
{[43.23]}\end{array}$ & $\begin{array}{c}117865 \\
(23573.00)\end{array}$ & $\begin{array}{c}97579 \\
(19515.80)\end{array}$ & $\begin{array}{l}215444 \\
{[54.71]}\end{array}$ & 49.15 & -5.97 & 17.86 \\
\hline & Medium & $\begin{array}{l}42340 \\
(8468) \\
\end{array}$ & \begin{tabular}{|l|}
186165 \\
$(37233)$ \\
\end{tabular} & $\begin{array}{l}228505 \\
{[18.53]}\end{array}$ & $\begin{array}{c}49805 \\
(9961.00) \\
\end{array}$ & $\begin{array}{c}245597 \\
(49119.40) \\
\end{array}$ & $\begin{array}{l}295402 \\
{[16.86]}\end{array}$ & 17.63 & 31.92 & 29.27 \\
\hline \multirow[t]{2}{*}{$\begin{array}{l}\text { Goulbur } \\
\text { Marshal }\end{array}$} & Very Poor & $\begin{array}{c}687328 \\
(18087.58) \\
\end{array}$ & \begin{tabular}{|c|}
430805 \\
$(11336.97)$ \\
\end{tabular} & $\begin{array}{c}1118133 \\
{[61.47]} \\
\end{array}$ & $\begin{array}{c}1275764 \\
(33572.74) \\
\end{array}$ & $\begin{array}{c}252136 \\
(6635.16) \\
\end{array}$ & $\begin{array}{c}1527900 \\
{[83.50]}\end{array}$ & 85.61 & -41.47 & 36.65 \\
\hline & Poor & $\begin{array}{c}341093 \\
(16242.52) \\
\end{array}$ & $\begin{array}{c}532992 \\
(25380.52) \\
\end{array}$ & $\begin{array}{l}874085 \\
{[39.02]}\end{array}$ & \begin{tabular}{|c|}
659358 \\
$(31398.00)$ \\
\end{tabular} & $\begin{array}{c}534940 \\
(25473.33) \\
\end{array}$ & $\begin{array}{c}1194298 \\
{[55.21]}\end{array}$ & 93.30 & 0.37 & 36.63 \\
\hline \multirow[t]{2}{*}{ Amjuri } & Very Poor & $\begin{array}{c}475577 \\
(20677.26) \\
\end{array}$ & $\begin{array}{c}293027 \\
(12740.30) \\
\end{array}$ & $\begin{array}{l}768604 \\
{[61.88]}\end{array}$ & $\begin{array}{c}837200 \\
(36400.00) \\
\end{array}$ & $\begin{array}{c}289315 \\
(12578.91) \\
\end{array}$ & $\begin{array}{c}1126515 \\
{[74.32]}\end{array}$ & 76.04 & -1.27 & 44.67 \\
\hline & Poor & $\begin{array}{c}51284 \\
(17094.67)\end{array}$ & $\begin{array}{c}620114 \\
(206704.66)\end{array}$ & $\begin{array}{c}671398 \\
{[7.64]}\end{array}$ & $\begin{array}{c}86625 \\
(28875.00)\end{array}$ & $\begin{array}{c}70407 \\
(23469.00)\end{array}$ & $\begin{array}{l}157032 \\
{[55.16]}\end{array}$ & 68.91 & -88.65 & -76.61 \\
\hline
\end{tabular}

Note: Figures in ( ) indicate average net return from forest/other sources per household.

Figures in [] represent percentage net return from forest sources of net return from all sources.

* indicates that the difference is statistically significant at 1 per cent level.

Source: Sample Survey.

sample JFM villages are engaged in illegal collection of TFPs $^{3}$, although the quantity of collection has significantly decreased in JFM villages after JFM Programme in relation to their past when the programme was not in operation. But, more importantly, the illegal collection of TFPs has substantially increased to one(Goulber Marshal) out of four JFM villages by both very poor and poor categories of households (Table 5). This is, mainly, because the rate of increase of the collection of other legal Forest Products (FPs) -like Fodder (Table 2) Fuelwood (Table 3), NTFPs (Table 4). - which are also one of the main sources of livelihood security for very poor and poor categories of households, in the particular village (Goulber Marshal) by both the categories of households is substantially lower than that of the collection of same type of other legal FPs by same categories of households(very poor and poor )in other three villages. What it implies is that if the NTFPs, Fodder and Fuelwood (which are allowed to collect legally under JFM programme) are more (less) available in the JFM forests ,the forcible extraction of TFPs (which are illegal under JFM programme and that are threatening to sustainability of forest resource) by the poor and very poor categories of households significantly decreases (increases) in the JFM forests. It seems to imply that law cannot forcibly control the illegal collection of TFPs of the very poor and poor categories of households, who are almost dependent on FPs for their livelihood security, until and unless they are guaranteed with minimum livelihood security by other sources.
If we consider the break-up of net annual income (in Rs.) of JFM households, the legal and illegal income from JFM forests by JFM households will be clearly demarcated. First, we consider annual net return (in Rs.) of sample households from all sources, Table 6 shows that while the JFM Programme is in operation the contribution of net return (in Rs.) from forest sources out of the net return (in Rs.) from all sources works out to the major source of income for very poor and poor categories of households in all sample villages. It is also observed that the forest source was the major source of net income (in Rs.) particularly for very poor category of households before the execution of JFM Programme when the forest was mainly used for commercial purpose and the forest fringe communities were not legally allowed to use forest resources for their livelihood security. Despite the fact that the incidence of forest income for poor and very poor JFM households has considerably increased after JFM. as may be seen from Table 6, the net annual income (in Rs.) and net annual average household income (in Rs.) generated from forest resources for very poor and poor categories of households in sample villages have significantly increased due to JFM Programme compared with the past when the programme was not in operation, the rate of net increase for very poor and poor being in the range of 64.80-85.61 and 49.15 -93.31 respectively. On the other hand, the rate of increase in net return (in Rs.) is around 18 per cent for medium category of households in one JFM Village (Khatgeria), whereas in another JFM village( 
Table 7: Incremental Net Return (in Rs.) from Forest Sources of Sample Households Per Year.

\begin{tabular}{|c|c|c|c|c|c|c|c|c|c|c|c|c|c|c|}
\hline \multirow{3}{*}{$\begin{array}{l}\text { FPC/ } \\
\text { Village }\end{array}$} & \multirow{3}{*}{$\begin{array}{l}\text { Category } \\
\text { of } \mathrm{HH}\end{array}$} & \multicolumn{6}{|c|}{ Before } & \multicolumn{6}{|c|}{ After } & \multirow{3}{*}{$\begin{array}{c}\% \\
\text { Change } \\
\text { of net } \\
\text { return* }\end{array}$} \\
\hline & & \multicolumn{2}{|c|}{$\begin{array}{l}\text { NTFPs, Fuelwood } \\
\text { Fodder }\end{array}$} & \multirow{2}{*}{$\begin{array}{l}\text { Return } \\
\text { from } \\
\text { Timber } \\
\text { sale }\end{array}$} & \multirow{2}{*}{$\begin{array}{c}\text { Return } \\
\text { from } \\
\text { Timber } \\
\text { Share }\end{array}$} & \multirow{2}{*}{$\begin{array}{c}\text { Wage } \\
\text { income } \\
\text { from } \\
\text { forest }\end{array}$} & \multirow{2}{*}{$\begin{array}{c}\text { Net } \\
\text { Return } \\
\text { from all } \\
\text { Forest } \\
\text { source }\end{array}$} & \multicolumn{2}{|c|}{$\begin{array}{l}\text { NTFPs, Fuelwood } \\
\text { Fodder }\end{array}$} & \multirow{2}{*}{$\begin{array}{c}\begin{array}{c}\text { Return } \\
\text { from }\end{array} \\
\text { Timber } \\
\text { sale }\end{array}$} & \multirow{2}{*}{$\begin{array}{c}\text { Return } \\
\text { from } \\
\text { Timber } \\
\text { Share }\end{array}$} & \multirow{2}{*}{$\begin{array}{l}\text { Wage } \\
\text { income } \\
\text { from } \\
\text { forest }\end{array}$} & \multirow{2}{*}{$\begin{array}{l}\text { Net return } \\
\text { from all } \\
\text { forest } \\
\text { source }\end{array}$} & \\
\hline & & $\begin{array}{l}\text { Consump } \\
\text { tion }\end{array}$ & Sale & & & & & $\begin{array}{l}\text { Consump } \\
\text { tion }\end{array}$ & Sale & & & & & \\
\hline \multirow[t]{3}{*}{ Kherajhore } & $\begin{array}{l}\text { Very } \\
\text { Poor }\end{array}$ & $\begin{array}{l}105120 \\
(5840)\end{array}$ & $\begin{array}{l}197100 \\
(10950)\end{array}$ & $\begin{array}{l}11859 \\
(659)\end{array}$ & & $\begin{array}{l}6324 \\
(351)\end{array}$ & $\begin{array}{l}314079 \\
(17449)\end{array}$ & $\begin{array}{l}124830 \\
(6935)\end{array}$ & $\begin{array}{l}315360 \\
(17520)\end{array}$ & $\begin{array}{l}39420 \\
(2190)\end{array}$ & $\begin{array}{l}6498 \\
(361)\end{array}$ & $\begin{array}{l}31500 \\
(1750\end{array}$ & $\begin{array}{l}517608 \\
(28756)\end{array}$ & 64.80 \\
\hline & Poor & $\begin{array}{l}91980 \\
(7665)\end{array}$ & $\begin{array}{l}96360 \\
(8030)\end{array}$ & $\begin{array}{l}2913 \\
(243)\end{array}$ & & $\begin{array}{l}2175 \\
(181)\end{array}$ & $\begin{array}{l}191253 \\
(15937)\end{array}$ & $\begin{array}{c}100740 \\
(8395)\end{array}$ & $\begin{array}{l}157680 \\
(13140)\end{array}$ & $\begin{array}{l}17520 \\
(1460)\end{array}$ & $\begin{array}{l}4332 \\
(361)\end{array}$ & $\begin{array}{l}13250 \\
(1104)\end{array}$ & $\begin{array}{l}293522 \\
(24460)\end{array}$ & 53.47 \\
\hline & Medium & $\begin{array}{r}16060 \\
(8030)\end{array}$ & $\begin{array}{c}3650 \\
(1825)\end{array}$ & $\begin{array}{c}913 \\
(457)\end{array}$ & & - & $\begin{array}{c}20623 \\
(10312)\end{array}$ & $\begin{array}{l}18250 \\
(9125)\end{array}$ & - & - & $\begin{array}{c}722 \\
(361)\end{array}$ & - & $\begin{array}{l}18972 \\
(9486)\end{array}$ & -8.01 \\
\hline \multirow[t]{3}{*}{ Khatgeria } & $\begin{array}{l}\text { Very } \\
\text { Poor }\end{array}$ & $\begin{array}{l}38325 \\
(5475)\end{array}$ & $\begin{array}{c}71540 \\
(10220)\end{array}$ & $\begin{array}{l}4382 \\
(626)\end{array}$ & & $\begin{array}{l}2728 \\
(390)\end{array}$ & $\begin{array}{l}114247 \\
(16321)\end{array}$ & $\begin{array}{l}48545 \\
(6935)\end{array}$ & $\begin{array}{c}114975 \\
(16425)\end{array}$ & $\begin{array}{l}12775 \\
(1825)\end{array}$ & $\begin{array}{l}5852 \\
(836)\end{array}$ & $\begin{array}{l}13580 \\
(1940)\end{array}$ & $\begin{array}{r}195727 \\
(27961)\end{array}$ & 71.32 \\
\hline & Poor & $\begin{array}{c}36500 \\
((7300)\end{array}$ & $\begin{array}{l}40150 \\
(8030)\end{array}$ & $\begin{array}{l}2374 \\
(475)\end{array}$ & & $\begin{array}{c}925 \\
(185)\end{array}$ & $\begin{array}{c}790241 \\
(15805)\end{array}$ & $\begin{array}{l}43800 \\
(8760)\end{array}$ & $\begin{array}{c}62050 \\
(12410)\end{array}$ & $\begin{array}{l}3650 \\
(730)\end{array}$ & $\begin{array}{l}4180 \\
(836)\end{array}$ & $\begin{array}{l}4185 \\
(837)\end{array}$ & $\begin{array}{c}117865 \\
(23573)\end{array}$ & 49.15 \\
\hline & Medium & $\begin{array}{l}40150 \\
(8030)\end{array}$ & - & $\begin{array}{l}2190 \\
(438)\end{array}$ & & - & $\begin{array}{l}42340 \\
(8468)\end{array}$ & $\begin{array}{l}45625 \\
(9125)\end{array}$ & - & - & $\begin{array}{l}4180 \\
(836)\end{array}$ & - & $\begin{array}{l}49805 \\
(9961)\end{array}$ & 17.63 \\
\hline \multirow[t]{2}{*}{$\begin{array}{l}\text { Goulbur } \\
\text { Marshal }\end{array}$} & $\begin{array}{l}\text { Very } \\
\text { Poor }\end{array}$ & $\begin{array}{c}235790 \\
(6205)\end{array}$ & $\begin{array}{l}443840 \\
(11680)\end{array}$ & $\begin{array}{l}7698 \\
(203) \\
\end{array}$ & & $\begin{array}{c}1476 \\
(39)\end{array}$ & $\begin{array}{l}687328 \\
(18088)\end{array}$ & $\begin{array}{c}177400 \\
(4668)\end{array}$ & $\begin{array}{c}268670 \\
(7070)\end{array}$ & $\begin{array}{l}817650 \\
(21517)\end{array}$ & $\begin{array}{c}3724 \\
(98)\end{array}$ & $\begin{array}{l}8320 \\
(219)\end{array}$ & $\begin{array}{c}1275764 \\
(33573)\end{array}$ & 85.61 \\
\hline & Poor & $\begin{array}{l}158297 \\
(7538)\end{array}$ & $\begin{array}{c}176295 \\
(8395)\end{array}$ & $\begin{array}{l}3833 \\
(183)\end{array}$ & & $\begin{array}{l}2668 \\
(127)\end{array}$ & $\begin{array}{l}341093 \\
(16243)\end{array}$ & $\begin{array}{c}191625 \\
(9125)\end{array}$ & $\begin{array}{l}222285 \\
(10585)\end{array}$ & $\begin{array}{l}229950 \\
(10950)\end{array}$ & $\begin{array}{c}2058 \\
(98)\end{array}$ & $\begin{array}{l}13440 \\
(640)\end{array}$ & $\begin{array}{c}659358 \\
(31398)\end{array}$ & 93.31 \\
\hline \multirow[t]{2}{*}{ Amjuri } & $\begin{array}{l}\text { Very } \\
\text { Poor }\end{array}$ & $\begin{array}{l}111888 \\
(4865)\end{array}$ & $\begin{array}{l}352590 \\
(15330)\end{array}$ & $\begin{array}{l}5457 \\
(237)\end{array}$ & & $\begin{array}{l}5642 \\
(245)\end{array}$ & $\begin{array}{l}475577 \\
(20677)\end{array}$ & $\begin{array}{c}142715 \\
(6205)\end{array}$ & $\begin{array}{l}562465 \\
(24455)\end{array}$ & $\begin{array}{l}100740 \\
(4380)\end{array}$ & - & $\begin{array}{l}31280 \\
(1360)\end{array}$ & $\begin{array}{l}837200 \\
(36400)\end{array}$ & 76.04 \\
\hline & Poor & $\begin{array}{l}19470 \\
(6490)\end{array}$ & $\begin{array}{c}30660 \\
(10220)\end{array}$ & $\begin{array}{c}914 \\
(305)\end{array}$ & & $\begin{array}{l}240 \\
(80)\end{array}$ & $\begin{array}{c}51284 \\
(17095)\end{array}$ & $\begin{array}{c}32995 \\
(10998)\end{array}$ & $\begin{array}{c}50180 \\
(16727)\end{array}$ & $\begin{array}{l}2190 \\
(730)\end{array}$ & & $\begin{array}{l}1260 \\
(420)\end{array}$ & $\begin{array}{c}86625 \\
(28875)\end{array}$ & 68.91 \\
\hline
\end{tabular}

Note: *Indicates that the difference is statistically significant at 1 per cent level.

Figures in ( ) indicate average net return from forest/other sources per household. Source: Sample Survey.

Kherajhore) this change is negative for medium category. It might suggest that very poor and poor categories of households are more dependent on income from forest resources; but medium category of households is more dependent on their income from non-forest sources.

As regards average household annual net forest income from legal wage work is concerned, Table 7 shows that the average household wage income under forest department for poor and very poor households after JFM is considerably higher in all JFM villages except one (Goulber marshal). It is important to mention that government wage rate for forest wage labour is fixed at Rs. 67.50, which is about a double of the average local wage rate. But the number of working days as wage labour under forest department for the poor forest fringe communities under JFM programme is more or less fixed. Usually, one person from each poor household gets the opportunity of forest work from 30-40 days per year. Moreover, significantly, the opportunities of legal wage income under forest department for the poor forest fringe communities in Goulber marshal JFM village is much lower than other JFM villages, because unlike the other JFM forests, the expansion of scope of wage work opportunities for the poor and very poor JFM households by the Forest department(Government) in Goulber marshal JFM forest depends on the new plantation programme, which seems to be not viable in the very short period,

As regards average household' annual net forest product income from legal and illegal source is concerned, Table 7 reveals that the legal average household income that income from the share of government's timber revenue and wages from forestry work constitute a small part of their total income, whereas income from the sale of NTFPs,Fuelwood and Fodder constitute the significant part of their total income. But, the legal average household income that appears from the sale of NTFPs, Fuelwood and Fodder is significantly higher in all JFM villages compared with the rest (Goulber Marshal) for poor and very poor households after JFM, whereas the illegal average household income that appears from the sale of TFPs is significantly lower in all JFM villages compared with the rest (Goulber Marshal) for poor and very poor households during the same period. It might suggest that if the NTFPs, Fodder and Fuelwood (which are allowed to collect legally under JFM programme) are more (less) available in the JFM forests, the forcible extraction of TFPs (which are illegal under JFM programme and that are threatening to sustainability of forest resource) by the poor and very poor categories of households decreases (increases) significantly in the JFM forests. It clearly seems to indicate that force or law cannot effectively control the illegal collection of Timber Forest Product (TFPs) of the very poor and poor categories of households until and unless a considerable collection of legal forest products like fuelwood, NTFPs meet their minimum livelihood security.

\section{Section VI}

Can IFM Programme sustain rural livelihoods, and thereby ensure sustainability of forest resources? The JFM Programme based on the National Forest Policy of 1988 in India lays emphasis on meeting local needs by supporting them fuelwood, fodder, food, NTFPs and limited use of TFPs 
for self consumption, prohibiting the free collection of TPs by the local people to maintain the carrying capacity of forest. Instead of free collection of TFPs by the local people, they are given a 25 per cent of share from the sell of timber by the forest department/government. But despite forbidden by law regarding the free collection of TFPs, the very poor and poor categories of households in one FPC/Village have substantially increased their collection of TPs after JFM Programme, mainly, because the other source of forest income - legal collection of fodder, fuelwood, NTFPs and wage income etc. - is substantially low for them in relation to the same categories of households in other three FPCs/Villages. Clearly, it implies that force or law cannot effectively control the illegal collection of TFPs for the households living below poverty line, which mainly dependent on forest resource for livelihood security, until and unless a considerable increase in the collection of legal forest products - NTFPs, fuelwood etc. - and wage income from forest meets their minimum livelihood security.

What are the probable policy prescriptions in order to overcome this situation? There seems to be three ways to tackle the situation. As regards the issue is concerned, as the production of forest products (like NTFPs) the very poor households legally collect from forest do not usually increase within the very short period. Regarding the second issue, as appears from this paper, a good incentive fee dependent on poor households' work (output) might not only provide livelihood sustenance of those poor living below poverty line and ensure sustainability of forest resources because the number of working days as wage labour under forest department for the poor forest fringe communities under JFM programme is more or less fixed and, and cannot be increased considerably within the very short period due to production constraints. Also important is that unlike the other JFM forests, the expansion of scope of work opportunities for the poor and very poor JFM households by the Forest department(Government) in Goulber marshal JFM forest , which witnessed high incidence of the forcible extraction of TFPs for bare minimum level of subsistence for very poor and poor JFM households, which consist of about 44 per cent of total households under survey (59 out of 134 cases) ,depends on the new plantation programme; but such a programme seems to be not viable in the very short period .However, the third- a good incentive fee dependent on very poor and poor JFM households' forest wage work (output) under forest department plus a lump sum fee - might be the immediate viable option for livelihood sustenance of those JFM households and sustainability of forest resources. Together with it, more pro-poor programmes under both Government and non-Government initiatives that complement the benefit of JFM Programme need to be introduced.

[The financial help for this paper has been taken from my UGC project entitled 'How to execute the Joint Forest Management Programme with Sustainability: A study of Joint FPC and Female FPC in four divisions under Midnapore and Bankura Districts in West Bengal'. The usual disclaimers apply.]

\section{Notes}

1. JFM household is risk-averse because they prefer a certain given forest income either from legal source or from illegal source to maintain minimum subsistence needs to a risky income with the same expected value.

2. Government is indifferent between a certain given income and an uncertain income with the same expected value. It may be judged by the fact that SFR (2000) clearly mentions "as a result of participatory and joint forest management activities in south West Bengal the vast tract of scattered, over-exploited and degraded forests containing mainly the sal were resuscitated and restored to productivity with great improvement in quality and density" (p. 47). Thus due to execution of JFM programme the large scale illicit felling of TFPs, which destroys the sustainability of forest resource, have been largely stopped mainly due to free access of NTFPs by the poor forest communities in most of JFM forests. However, the impact of little illicit felling does not seem to make any significant change between a certain given income and an uncertain income with the same expected utility.

3. Never did the respondents say that their source of income was illegal; rather, while examining the answers from the respondents regarding the break-up of their source of income, the distinction between legal and illegal source was clearly demarcated.

\section{Reference}

Baland, J. M. and J. P. Platteau (1996): Halting Degradation of Natural Resources: Is there a Role for Rural Communities, Clarendon Press, Oxford.

Berkes, F. (ed.) (1989), Common Property Resources. Ecology and Community Based Sustainable Development, Belhaven Press, London.

Bromley, D.W. (ed.) (1992), Making the Commons Work: Theory, Practice and Policy, Institute for Contemporary Studies Press, San Francisco.

Bezbaruah, D . K. (2004): 'Socio-economic Traits of the Kaibartas in the Brahamaputra Valley: An Empirical Study in Nalbari District, IASSI Quarterly, Vol. 22(3), pp. 102-129.

Correa, M. (1999), The Need for Emancipatory Research: Experiences from JFPM in Uttar Kannada, in R. Jeffery and N. Sundar (eds.) A New Moral Economy for India's Forests? Discourses of Community and Participation (pp. 216-234), Sage Publications, New Delhi.

Das, N. and D. Sarker (2008), Reforms in Forest Management in West Bengal: A Game of Strategic Profile, in D. Sarker (ed.), Second Generation Reforms (pp. 79-101), Allied Publishers Pvt. Ltd., New Delhi.

Das, N. and D. Sarker (2009a): 'Impact of Moral Hazard Problem in the Joint Forest Management Programme : a study from forestdependent households in West Bengal', Journal; of Economic Policy Reform, Vol. 12 , No. 4, December 2009, pp 323-331. 
Das, N. and D. Sarker (2009b): 'The framework of Household Model under the Joint Forest Management Programme: a study on forest-dependent household', The Indian Economic Journal, Vol. 57, No.3, October-December, pp 44-71.

Martin, F. (1992), 'Common Pool Resources and Collective Action: A Bibliography', Paper presented to the Workshop on Political Theory and Policy Analysis, Bloomington, Indiana.

Mukherjee, N. (1995), 'Forest Management and Survival Needs: Community Experience in West Bengal', Economic and Politically Weekly, Vol. 30, No. 49, pp. 3130-132.

Naik, G. (1997), 'Joint Forest Management: Factor Influencing Household Participation', Economic and Politically Weekly, Vol. 32, No.48, pp. 3084-3089.

Poffenberger, M. (1995), The Resurgence of Community Forest Management in the Jungle Mahals of West Bengal, in D. Arnold and R. C. Guha (eds.) Nature, Culture and Imperialism: Essays on the Environmental History of South Asia (336-69), Oxford University Press, Delhi.

Sarker, D.N. and N. Das (2002): 'Women's Participation in Forestry - Some Theoretical Issues', Economic andPolitical Weakly, October 26: P. 4407-12.

Sarker, D. and N. Das (2008), 'A Study of Economic Outcome of Joint Forest Management Programme in West Bengal: The Strategic
Decisions between Government and Forest Fringe Community', Indian Economic Review, Vol. 43, No. 1, pp.13-30.

Sarker, D (2009): Sustain Rural Livelidhoods under Joint Forest Management(JFM) Programme: some evidence from West Bengal, India, Artha Vijnana, Vol. LI, No. 1, March, 59-84.

Sarker, D. and N. Das (2006), 'Towards a Sustainable Joint Forest Management Programme: Evidence from Western Midnapore Division in West Bengal', South Asia Research, Vol. 26, No. 3, pp. 269-289.

Sarmah, D. and S. N. Rai (2001), Forest Resource Management in India: Role of the State and its Effectiveness, in S.N. Chary and V. Vyasulu (eds.) Environment and Management (206-220), Macmillan: New Delhi.

SFR (2000), State Forest Report, Office of the Principal Chief Conservator of Forest, Directorate of Forest, Government of West Bengal, Kolkata.

Sundar, N. and R. Jeffery (eds.) (1999), A New Moral Economy for India's Forests? Discourses of community and Participation (pp.15-54), Sage Publication, New Delhi.

World Bank (2006): 'India: Unlocking Opportunities for ForestDependen 
